\title{
Peran Kepemimpinan, Modal Sosial, Akses Informasi serta Petugas dan Fasilitator Kesehatan dalam Pemberdayaan Masyarakat Bidang Kesehatan
}

\author{
Roles of Leadership, Social Capital, Information Access as well as Health \\ Duty and Facilitator within Public Empowerment in Health Sector
}

\author{
Endang Sutisna Sulaeman*, Bhisma Murti*, Waryana**
}

\begin{abstract}
*Program Studi Magister Ilmu Kesehatan Masyarakat Pascasarjana Universitas Sebelas Maret, **Jurusan Gizi Politeknik Kesehatan Kementerian Kesehatan Yogyakarta
\end{abstract}

\begin{abstract}
Abstrak
Faktor internal komunitas yang berperan dalam pemberdayaan masyarakat bidang kesehatan adalah kepemimpinan dan modal sosial, sedangkan faktor eksternal komunitas yang berperan adalah akses informasi kesehatan, petugas dan fasilitator kesehatan. Tujuan penelitian adalah mengetahui dan menganalisis peran kepemimpinan, modal sosial, akses informasi kesehatan, petugas, dan fasilitator kesehatan dalam pemberdayaan masyarakat bidang kesehatan. Desain penelitian adalah potong lintang dengan pendekatan penelitian kualitatif melalui metode studi kasus terpancang. Penelitian dilakukan selama tiga bulan di Kabupaten Tulungagung, Jawa Timur dengan mengambil dua desa, yaitu Desa Bulus di Kecamatan Bandung dan Desa Tanggul Kundung di Kecamatan Besuki tahun 2013. Hasil penelitian menunjukkan bahwa peran kepemimpinan dalam pemberdayaan masyarakat bidang kesehatan pada program Desa Siaga adalah menyebarluaskan informasi, memberikan contoh, menyadarkan, memotivasi, membimbing, menggerakkan sasaran dan masyarakat, memfasilitasi dan mengalokasikan sumber daya. Peran modal sosial adalah saling percaya, kekerabatan, pertemanan, pertetanggaan, norma sosial, tolongmenolong, kerja sama, dan jaringan masyarakat. Peran akses informasi kesehatan adalah meningkatkan pengetahuan dan keterampilan kesehatan, mengambil keputusan, dan meminta pelayanan kesehatan. Peran petugas kesehatan adalah sosialisasi, memberikan petunjuk, melatih, membina, memfasilitasi, menumbuhkembangkan partisipasi, serta memantau dan mengevaluasi program. Sedangkan peran fasilitator kesehatan adalah sosialisasi, memotivasi, memengaruhi pengambilan keputusan, memediasi masyarakat dan pemerintah, memfasilitasi dan menumbuhkembangkan partisipasi.
\end{abstract}

Kata kunci: Akses informasi kesehatan, fasilitator kesehatan, kepemimpinan, modal sosial, peran petugas kesehatan

\footnotetext{
Abstract

The internal factors of community contributing to public empowerment in
}

health sector were leadership and social capital, meanwhile the external factors included health information access, health duty and facilitator. This study aimed to determine and analyze the roles of leadership, social capital, information access, and health duty and facilitator within public empowerment in health sector. The study design was cross sectional with qualitative study approach through embeded case study method. The study was conducted in Tulungagung District, East Java by taking two villages namely Bulus Village at Bandung Subdistrict and Tanggul Kundung Village at Besuki Subdistrict in 2013. The result showed the roles of leadership and public empowerment in health sector in Alert Village program were spreading information, giving examples, awakening, motivating, educating, moving targets and the public, facilitating and allocating resources. The roles of social capital were mutual trust, kinship, friendship, neighborhood, social norms, mutual help and public network. The roles of health information access were improving health knowledge and skill, making decision and asking for health services. The roles of health duty were socialization, giving instructions, training, building, facilitating, developing participation as well as monitoring and evaluating the program. Meanwhile, the roles of health facilitator were socialization, motivating, influencing decision making, mediating public and government, facilitating and developing participation.

Keywords: Health information access, health facilitator, leadership, social capital, roles of health duty

\section{Pendahuluan}

Tiga dari delapan tujuan Millenium Development Goals (MDGs) terkait dengan program Desa Siaga, di antaranya menurunkan prevalensi balita kekurangan gizi, telah berkurang hampir setengahnya, dari $31 \%$ pada

Korespondensi: Endang Sutisna Sulaeman, Prodi Magister IKM Pascasarjana Universitas Sebelas Maret Gd. Pascasarjana Lt.2, Jl. Ir. Sutami 36 A Kentingan Surakarta 57126, No.Telp: 0271-632450,e-mail: sutisnaend_dr@yahoo.com 
tahun 1989 menjadi 18,4\% pada tahun 2007 dan target pada tahun 2015 sebesar 15,5\%. Kemudian, tujuan mengurangi angka kematian anak sebesar dua per tiganya antara tahun 1990 - 2015, angka kematian bayi (AKB) telah menurun dari 68 per 1.000 kelahiran hidup pada tahun 1991 menjadi 34 per 1.000 kelahiran hidup pada tahun 2007 dan target pada tahun 2015 sebesar 32 per 1.000 kelahiran hidup. Sedangkan angka kematian balita (AKBA) telah menurun dari 97 per 1.000 kelahiran hidup pada tahun 1991 menjadi 44 per 1.000 kelahiran hidup pada tahun 2007 dan target pada tahun 2015 sebesar 32 per 1.000 kelahiran hidup. Selain itu, tujuan memperbaiki kesehatan maternal, yakni menurunkan angka kematian ibu (AKI) sebesar tiga per empatnya antara tahun 1990 - 2015, telah menurun dari 390 per 100.000 kelahiran hidup pada tahun 1991 menjadi 228 per 100.000 kelahiran hidup, namun, pada tahun 2012 meningkat menjadi 359 per 100.000 kelahiran hidup. ${ }^{1}$

Indonesia berulang kali masuk kategori negara yang lamban langkahnya dalam mencapai MDGs. Pencapaian MDGs belum mengikutsertakan masyarakat melalui pemberdayaan masyarakat. Masalah pemberdayaan masyarakat adalah lemahnya kemampuan mengidentifikasi dan memecahkan masalah kesehatan. ${ }^{2}$ Sejalan dengan itu, Hawe (cit. Yoo et $a l^{3}$ )mengemukakan bahwa pemberdayaan masyarakat bertujuan untuk meningkatkan kemampuan masyarakat dalam mengidentifikasi dan memecahkan masalah kesehatan yang dihadapi sehingga dapat meningkatkan kesehatan masyarakat secara keseluruhan. Sementara itu, Rehn et al, ${ }^{4}$ merumuskan model pemberdayaan masyarakat meliputi partisipasi, kepemimpinan, keterampilan, sumber daya, nilai-nilai, sejarah, jaringan, dan pengetahuan masyarakat.

Penelitian Sulaeman et al, ${ }^{5}$ menyimpulkan bahwa faktor internal komunitas yang berperan dalam pemberdayaan masyarakat bidang kesehatan adalah kepemimpinan dan modal sosial. Sedangkan faktor eksternal komunitas yang berperan adalah akses informasi, peran petugas dan fasilitator. Sementara itu, penelitian Ashwell et al, ${ }^{6}$ menyimpulkan bahwa faktor kunci yang memengaruhi kesehatan adalah desa dan kabupaten termotivasi dan individu terlatih sebagai katalis untuk perubahan, kepemimpinan diberdayakan, petunjuk praktis yang efektif, dan partisipasi kader kesehatan desa yang terlatih. Sedangkan kegagalan program kesehatan disebabkan pemahaman pemberdayaan masyarakat yang buruk, terbatasnya informasi, pendekatan top-down dan kepemimpinan masyarakat yang lemah.

Kouzes et al (cit. Sulaeman), ${ }^{7}$ menyimpulkan terdapat lima aspek kepemimpinan meliputi model the way, yaitu memberikan contoh dalam pelaksanaan kegiatan; inspire a shared vision, yaitu memberikan inspirasi pada visi bersama; challenge the process, yaitu melakukan pembaharuan dalam proses pencapaian tujuan; enable others to act, yaitu meningkatkan kemampuan staf untuk bertindak melalui kerja sama tim, memberikan kepercayaan, dan mengembangkan kemampuan staf serta encourage the heart, yaitu memberikan semangat dan penghargaan.

Macinko et al, ${ }^{8}$ melaporkan bahwa modal sosial berhubungan positif dengan status kesehatan. Jaringan sosial merupakan sumber fundamental untuk mencegah penyakit. Individu yang tinggal di komunitas dengan tingkat modal sosial tinggi melaporkan dirinya lebih sehat secara jasmani dan rohani dibandingkan individu yang tinggal dalam masyarakat dengan tingkat modal sosial rendah. Selanjutnya, Nahapiet et al (cit. Sulaeman), ${ }^{2}$ menjelaskan peran modal sosial dalam tiga bentuk, yaitu struktural, relasional, dan kognitif. Dimensi struktural berhubungan dengan kemampuan individu untuk membuat ikatan yang lemah menjadi kuat dalam suatu sistem. Dimensi relasional berfokus pada karakter koneksi antara individu yang berlandaskan kepercayaan dan kerjasama. Dimensi kognitif memfokuskan pada makna dan pemahaman bersama bahwa individu atau kelompok merasa memiliki satu dengan yang lain.

Menurut Keleher et al, ${ }^{9}$ akses informasi kesehatan adalah kemampuan seseorang dalam mengetahui dan bertindak untuk mendapatkan pelayanan kesehatan yang selayaknya. Akses informasi kesehatan diakui sebagai deteminan kunci dari kesehatan. Akses informasi adalah aktivitas warga masyarakat dalam memperoleh informasi melalui pelbagai cara, seperti melalui penyuluhan, pendidikan dan pelatihan kesehatan, media massa, media elektronika, dan lain-lain. Sementara itu, menurut Fineberg, 10 akses informasi kesehatan adalah kemampuan seseorang dalam memperoleh, memproses dan memahami informasi kesehatan untuk pengambilan keputusan yang tepat dalam mengakses layanan kesehatan yang dibutuhkan.

Peran petugas kesehatan menurut Kementerian Kesehatan adalah aktif dalam pengembangan dan penyelenggaraan upaya kesehatan bersumber daya masyarakat (UKBM) di Desa Siaga (poskesdes, posyandu, dan lainlain), menggerakkan masyarakat untuk mengelola, menyelenggarakan, dan memanfaatkan UKBM yang ada serta menyelenggarakan sosialisasi program kesehatan untuk menciptakan Keluarga Sadar Gizi (Kadarzi) dan Perilaku Hidup Bersih dan Sehat (PHBS). ${ }^{11}$ Sementara itu, peran fasilitator adalah katalis, yaitu mendorong timbulnya perasaan tidak puas di masyarakat mengenai hasil pembangunan yang ada; penemu solusi, yaitu memberikan kejelasan gagasan pembangunan yang direkomendasikan kepada sasaran perubahan; pendamping, yaitu mendampingi proses penentuan solusi masalah sebagai aplikasi inovasi pembangunan; perantara, yaitu mempersatukan antara dua kepentingan yakni 
pembuat kebijakan dan sasaran pembangunan dengan membuat keputusan terbaik; motivator, yaitu memberikan dorongan serta memfasilitasi proses pemberdayaan masyarakat. ${ }^{7}$

Penelitian ini bertujuan untuk mengetahui dan menganalisis peran kepemimpinan, modal sosial, akses informasi, peran petugas dan fasilitator kesehatan dalam pemberdayaan masyarakat bidang kesehatan pada program Desa Siaga.

\section{Metode}

Desain penelitian adalah potong lintang dengan pendekatan penelitian kualitatif melalui metode studi kasus terpancang. Penelitian dilakukan di Kabupaten Tulungagung, Jawa Timur dengan mengambil dua desa yaitu Desa Bulus di Kecamatan Bandung sebagai representasi Desa Siaga Utama dan Desa Tanggul Kundung di Kecamatan Besuki sebagai representasi Desa Siaga Pratama. Penelitian dilakukan selama tiga bulan dari Juli 2013 sampai dengan September 2013.

Populasi penelitian adalah situasi sosial dalam program Desa Siaga di Desa Bulus, Kecamatan Bandung dan Desa Tanggul Kundung, Kecamatan Besuki, Kabupaten Tulungagung, Provinsi Jawa Timur. Teknik pengambilan sampel dilakukan secara purposive dan snowball sampling. Teknik pengumpulan data dilakukan dengan cara wawancara mendalam, observasi partisipasi, dan kajian dokumen. Alat bantu yang digunakan untuk mengumpulkan data adalah pedoman wawancara mendalam, perekam, alat tulis, dan kamera. Jumlah informan kunci seluruhnya adalah 56 orang yang terdiri dari dua kategori, yaitu kelompok komunitas meliputi kepala desa dan perangkatnya, Badan Perwakilan Desa (BPD), Lembaga Pemberdayaan Masyarakat Desa (LPMD), ketua atau anggota tim penggerak Pembinaan Kesejahteraan Keluarga (PKK) tingkat desa serta kader Desa Siaga. Masing-masing desa sebanyak 15 orang sehingga terdapat 30 informan. Kategori kedua adalah kelompok petugas kesehatan meliputi tim pembina Desa Siaga puskesmas sejumlah 18 informan dan tim pembina Desa Siaga dinas kesehatan kabupaten sejumlah enam informan.

Observasi partisipasi dilakukan di dua poskesdes dan di masyarakat. Peneliti melakukan observasi terhadap aktivitas pelayanan kesehatan dengan mengamati lokasi, denah ruangan, alur, prosedur, jenis pelayanan, pencatatan dan pelaporan klien yang berkunjung. Kajian dokumen dilakukan terhadap pedoman, kebijakan, perencanaan, dan hasil program Desa Siaga di Dinas Kesehatan Kabupaten Tulungagung, unit pelaksana teknis dinas Puskesmas Bandung dan Puskesmas Besuki serta dua poskesdes. ${ }^{12}$

Unit analisis adalah program Desa Siaga di Kabupaten Tulungagung, Jawa Timur. Analisis data meliputi reduksi data, penyajian data, dan kesimpulan yang dilakukan secara interaktif dan siklik dengan proses pengumpulan data. Untuk memaksimalkan kepercayaan data, dilakukan beberapa jenis triangulasi di antaranya triangulasi peneliti, yaitu bekerja kolaboratif dalam tim penelitian dengan jumlah lima orang dalam mengidentifikasi kode, mengembangkan kategori dan tema. Kemudian, triangulasi metode dan sumber data, yaitu menggunakan pelbagai jenis data yang dikumpulkan dengan pelbagai metode dan sumber data, misalnya rekaman dari wawancara, catatan lapangan, dan pemeriksaan anggota untuk memberikan umpan balik hasil analisis data. Selanjutnya adalah triangulasi teori, yaitu penggunaan beberapa teori atau perspektif untuk menafsirkan kumpulan data.

Hasil triangulasi metode melalui wawancara mendalam tentang kepemimpinan sesuai dengan hasil pengamatan langsung yang dilakukan oleh peneliti saat berlangsung pertemuan antara warga dengan pamong desa, pengurus PKK desa, dan tokoh masyarakat. Sebagai pemimpin, para pamong desa, pengurus PKK Desa, maupun tokoh masyarakat memberikan motivasi, memberikan contoh, menggerakkan sasaran dan masyarakat. Kesimpulan dari dalam tim penelitian dengan jumlah lima orang menguatkan kesimpulan bahwa modal sosial di Desa Bulus, Kecamatan Bandung dan Desa Tanggul Kundung, Kecamatan Besuki berhubungan dengan kemampuan masyarakat dalam hal identifikasi dan pemecahan masalah kesehatan.

\section{Hasil \\ Karakteristik Informan}

Berdasarkan karakteristik informan pada Tabel 1, dari 56 informan, jenis kelamin laki-laki sebanyak 46,43\% dan perempuan sebanyak $53,67 \%$. Rata-rata usia informan adalah 42,7 tahun dengan rentang terendah 27 tahun dan yang paling tua berusia 54 tahun. Sebagian besar informan berusia 24 - 39 tahun $(53,57 \%)$ dan berusia 40 - 55 tahun $(46,43 \%)$. Ditinjau dari segi pendidikan, persentase informan berpendidikan tingkat perguruan tinggi (PT) adalah 35,71\%, diploma 3 (D3) $10,71 \%$, sekolah menengah atas (SMA) $35,50 \%$, sekolah menengah pertama (SMP) $14,28 \%$, dan sekolah dasar

Tabel 1. Karakteristik Informan

\begin{tabular}{llll}
\hline Karakteristik & Kategori & Jumlah & Persentase \\
\hline Jenis kelamin & Laki-laki & 26 & 46,43 \\
& Perempuan & 30 & 53,57 \\
Usia & $24-39$ tahun & 30 & 53,57 \\
& $40-55$ tahun & 26 & 46,43 \\
\multirow{3}{*}{ Pendidikan } & 55 tahun & 0 & 0,0 \\
& PT & 20 & 35,71 \\
& D3 & 6 & 10,71 \\
& SMA & 21 & 37,50 \\
& SMP & 8 & 14,28 \\
& SD & 1 & 1,78 \\
\hline
\end{tabular}


(SD) $1,78 \%$.

Hasil observasi partisipasi di dua poskesdes dan di masyarakat menyimpulkan bahwa poskesdes dikelola oleh tenaga kesehatan, yaitu bidan dan perawat. Poskesdes berperan sebagai UKBM yang dibentuk di desa dalam rangka mendekatkan pelayanan kesehatan dasar. Kegiatan poskesdes mencakup upaya pelayanan kesehatan dasar secara menyeluruh secara promotif, preventif dan kuratif, termasuk pengamatan dan kewaspadaan dini, penanganan hal yang bersifat gawat darurat, dan kesiapsiagaan terhadap bencana. Pengunjung poskesdes adalah ibu hamil, bayi, anak balita, perempuan usia subur, usia lanjut, dan masyarakat lainnya. Pelayanan dilaksanakan baik di dalam maupun di luar gedung.

Berdasarkan observasi, tampak bahwa kepemimpinan dan modal sosial berperan dalam keberhasilan pemberdayaan masyarakat melalui gotong-royong masyarakat, adanya organisasi kelompok yasinan, pertemuan rukun tetangga (RT), dan pertemuan forum Desa Siaga sebagai media komunikasi dan kerja sama antara warga dengan pemimpin desa dan petugas kesehatan.

Berdasarkan kajian dokumen terhadap cakupan program Desa Siaga tahun 2012, persentase tingkat partisipasi masyarakat (D/S) adalah 71,95\%, yaitu jumlah balita yang ditimbang berjumlah 59.640 dari 82.894 anak dengan cakupan balita berat badan naik $(71,09 \%)$, bayi yang diberi ASI eksklusif $(51,20 \%)$, balita mendapatkan vitamin A dua kali $(90,96 \%)$, balita dengan gizi buruk sejumlah 243 anak $(0,41 \%)$, sedangkan balita gizi kurang sejumlah 2.476 orang $(4,15 \%)$. Universal Child Immunization (UCI) adalah $74,17 \%$ dari jumlah 271 desa. Cakupan imunisasi campak bayi adalah $100,78 \%$. Drop out imunisasi DPT1-campak adalah 5,65\%. Jumlah kasus penyakit yang dapat dicegah dengan imunisasi (PD3I) yaitu 17 kasus difteri, empat kasus campak dan tujuh kasus hepatitis klinis. Kunjungan ibu hamil (K1) adalah 91,66\% dan kunjungan ibu hamil (K4) 85,03\%. Cakupan persalinan ditolong tenaga kesehatan adalah $89,57 \%$, pelayanan ibu nifas $86,38 \%$, peserta Keluarga Berencana (KB) baru 13,61\%, sedangkan peserta KB aktif $67,34 \%$.

Cakupan PHBS rumah tangga adalah 35,32\%, rumah sehat $57,80 \%$, rumah/bangunan bebas jentik $92,78 \%$, keluarga dengan sumber air minum terlindung $56,84 \%$, keluarga memiliki jamban sehat $66,48 \%$, keluarga memiliki tempat sampah sehat $82,09 \%$, keluarga memiliki pengelolaan air limbah sehat $61,33 \%$, dan institusi dibina kesehatan lingkungannya $79,62 \%$. Jumlah kematian ibu adalah 11 jiwa dari 16.109 jiwa kelahiran hidup (68,28 per 100.000 kelahiran hidup). Angka kematian bayi adalah 121 jiwa dari 16.109 jiwa kelahiran hidup (7,51 per 1.000 kelahiran hidup) dan angka kematian balita adalah 138 jiwa dari 59.848 jiwa $(8,57$ per 1.000 kelahiran hidup).

\section{Peran Kepemimpinan dalam Pemberdayaan Masyarakat Bidang Kesehatan}

Dari studi kasus terungkap bahwa peran kepemimpinanan dalam pemberdayaan masyarakat bidang kesehatan pada program Desa Siaga adalah menyebarluaskan informasi, memberikan contoh dan sebagai panutan, menyadarkan, memotivasi, membimbing, menggerakkan sasaran dan masyarakat, memfasilitasi dan mengalokasikan sumber daya.

Peran Kepemimpinan dalam Menyebarluaskan Informasi

Terungkap dari penuturan informan sebagai berikut:

"...Peran pemimpin adalah melakukan sosialisasi dan penyuluhan kepada masyarakat agar masyarakat mengetahui dan memahami adanya masalah kesehatan di masyarakat. Sosialisasi dilakukan pada pertemuan Yasinan (membaca al-Qur'an Surat Yaasin), pertemuan warga RT, dan posyandu." (Mh, Bulus, 23 Agustus 2013)

\section{Peran Kepemimpinan dalam Penyadaran dan Motivasi}

Seperti penuturan informan berikut:

"...Pemimpin masyarakat berperan dalam memotivasi dan mendorong masyarakat dalam upaya penanggulangan masalah kesehatan dan gizi...” (Sns, Bulus, 23 Agustus 2013)

\section{Peran Kepemimpinan dalam Membimbing, Menggerakkan Sasaran dan Masyarakat}

Sebagaimana disampaikan oleh informan berikut:

"...Peran pemimpin masyarakat adalah menyadarkan, mengajak dan menggerakan masyarakat serta menyediakan tempat kegiatan seperti posyandu, membimbing masyarakat agar bergotong-royong dalam pemecahan masalah kesehatan...” (Mh, Bulus, 22 Agustus 2013)

\section{Peran Kepemimpinan dalam Memberikan Contoh dan Sebagai Panutan \\ Seperti penuturan informan berikut: \\ "...Pimpinan masyarakat berperan sebagai panutan warga masyarakat dalam upaya kesehatan dan gizi, se- hingga kalau Pak Lurah dan Pak Kepala Dusun mem- beri nasihat, masyarakat akan mengikutinya..." (Srs, Bulus, 23 Agustus 2013). \\ "...Pemimpin memberikan contoh. Kalau pemimpin hanya memberikan saran, tapi tidak memberikan con- toh, sarannya tidak didengar..." (Ags, Bandung, 24 Agustus 2013)}

\footnotetext{
Peran Kepemimpinan dalam Memfasilitasi dan Mengalokasikan Sumber Daya

Sebagaimana penuturan informan berikut:
} 
“...Pemimpin menyadarkan masyarakat, mengarahkan masyarakat tentang pentingnya kesehatan, dan melakukan penggerakan pengumpulan dana sosial untuk kesehatan..." (Rs, Bulus, 22 Agustus 2013)

"...Peran pimpinan masyarakat adalah memberikan bantuan. Kalau ada keluarga atau masyarakat yang kurang mampu, pimpinan desa melakukan penggalangan dan pengumpulan dana. Desa juga memberi stimulan dana ke setiap dusun ...” (Knp, Tanggul, 24 Agustus 2013).

Dari kutipan pernyataan informan tersebut, dapat disimpulkan bahwa peran pimpinan masyarakat adalah menyebarluaskan informasi tentang program Desa Siaga kepada masyarakat, memberi contoh perilaku seharihari, mulai dari keluarga sendiri, dan di fasilitas umum seperti kantor balai desa. Peran tersebut dapat menumbuhkan partisipasi masyarakat terhadap program Desa Siaga. Dengan peran pimpinan tersebut, maka akan timbul partisipasi masyarakat dalam pelaksanaan dan kelangsungan program Desa Siaga.

\section{Peran Modal Sosial dalam Pemberdayaan Masyarakat Bidang Kesehatan \\ Peran modal sosial dalam pemberdayaan masyarakat bidang kesehatan meliputi adanya saling percaya an- tarkeluarga dan masyarakat, kerja sama antara warga masyarakat, pimpinan dan petugas kesehatan, saling to- long-menolong, norma sosial timbal-balik, hubungan kekerabatan, pertetanggaan dan pertemanan serta adanya jaringan organisasi masyarakat.}

Adanya Saling Percaya Antarkeluarga, Masyarakat, dan Petugas Kesehatan

Sebagaimana disampaikan oleh informan berikut:

“...Warga masyarakat saling percaya, sehingga terjalin kerja sama dalam pemecahan masalah kesehatan secara gotong royong. Ikatan sosial antarwarga masyarakat sangat kuat dan bersatu-padu..." (Nn, Bandung, 24 Agustus 2013)

“...Adanya rasa memiliki antarwarga, ditunjukkan bila ada warga yang sakit, maka warga saling memberitahu satu sama lain dan berkunjung kepada orang yang sakit, serta memberikan sumbangan..." (Snt, Bandung, 24 Agustus 2013)

"Kepercayaan warga masyarakat terhadap bidan desa besar sekali sehingga setiap melahirkan ditolong oleh bidan. Juga kalau warga sakit, warga berobat ke Pos Kesehatan Desa." (Srt, Bulus, 23 Agustus 2013)

\footnotetext{
Adanya Hubungan Kekerabatan, Pertetanggaan, dan Pertemanan

Sebagaimana dituturkan oleh informan berikut:

"...Adanya kekerabatan dan kedekatan antarwarga masyarakat berperan dalam mengidentifikasi dan
}

memecahkan masalah kesehatan, misalnya tetangga memberikan saran, nasihat, atau informasi kesehatan dan memberitahukan masalah kesehatan atau penyakit yang diderita oleh tetangganya..." (Srt, Bulus, 23 Agustus 2013)

Adanya Kerja Sama antara Warga Masyarakat, Pimpinan, dan Petugas Kesehatan serta Adanya Jaringan Organisasi Masyarakat

Terungkap dari penuturan informan berikut:

"...Melalui kerja sama antarwarga, masalah kesehatan dapat ditanggulangi. Kerja sama diwujudkan dalam pelbagai bentuk, seperti kerja bakti atau gotongroyong, pengumpulan iuran dana sehat..." (Ans, Bandung, 24 Agustus 2013)

"Adanya organisasi masyarakat seperti kelompok yasinan, pertemuan RT, pertemuan Dasa Wisma merupakan modal sosial yang dapat mempermudah kerja sama antara warga masyarakat serta kerja sama dengan pimpinan desa dan petugas kesehatan dalam pemecahan masalah kesehatan..."(Bdn, Bulus, 23 Agustus 2013)

"...Modal sosial di desa adalah gotong-royong masyarakat dalam melaksanakan posyandu dan membantu keluarga gizi buruk serta memotivasi masyarakat untuk selalu menjaga kesehatan lingkungan, memberikan nasihat kepada ibu balita agar selalu menimbangkan balitanya setiap bulan serta memerhatikan gizi dan kesehatan anaknya, kader kesehatan bergotong-royong dalam melaksanakan program posyandu dan Desa Siaga..." (Sp, Bandung, 24 Agustus 2013)

Modal sosial yang terdapat di masyarakat merupakan perekat antara individu satu sama lain, seperti adanya kebiasaan saling mengunjungi apabila terdapat tetangga yang baru melahirkan, warga masyarakat yang sakit, atau dirawat di rumah sakit. Kebiasaan ini sebagai modal sosial untuk tercapainya derajat kesehatan masyarakat secara optimal.

\section{Peran Akses Informasi Kesehatan dalam Pemberdayaan} Masyarakat Bidang Kesehatan

Sebagian besar informan mengatakan bahwa akses informasi kesehatan berperan dalam pemberdayaan masyarakat bidang kesehatan melalui peningkatan pengetahuan dan keterampilan kesehatan, mengambil keputusan kesehatan, dan meminta pelayanan kesehatan.

Peran Akses Informasi Kesehatan dalam Mengambil Keputusan Kesehatan dan Meminta Pelayanan Kesehatan

Sebagaimana penuturan informan berikut:

"...Akses informasi kesehatan berperan dalam mengidentifikasi dan memecahkan masalah kesehatan, misalnya Depkes menayangkan informasi kesehatan di TV, seperti biaya persalinan gratis melalui jaminan persalinan, masyarakat menanyakan kepada petugas puskesmas 
bagaimana syarat dan tata caranya...” (Bd. Bulus, 22 Agustus 2013)

Peran Akses Informasi Kesehatan dalam Meningkatkan Pengetahuan dan Ketrampilan Kesehatan

Sebagaimana disampaikan informan berikut:

"...Penyampaian informasi kesehatan berdampak pada peningkatan kemampuan pengetahuan dan keterampilam kesehatan bagi masyarakat...." (Tn, Bandung, 24 Agustis 2013)

“...Perolehan informasi kesehatan membuat masyarakat lebih memahami masalah kesehatan dan mengetahui bagaimana cara mengatasi masalah kesehatan di desa..." (Srt, Bulus, 22 Agustus 2013)

Akses informasi kesehatan diperoleh masyarakat dari petugas puskesmas dan media massa seperti televisi dan radio. Melalui sumber informasi tersebut, masyarakat memperoleh pengetahuan tentang cara hidup sehat, cara merawat kesehatan perorangan, cara menjaga kebersihan lingkungan, cara merawat kehamilan, cara merawat bayi, dan sebagainya. Mudahnya akses informasi yang diperoleh masyarakat akan meningkatkan pengetahuan masyarakat tentang perilaku hidup bersih dan sehat.

\section{Peran Petugas Kesehatan dalam Pemberdayaan Masyarakat Bidang Kesehatan}

Beberapa informan menyampaikan bahwa peran petugas kesehatan adalah melakukan sosialisasi, memberikan petunjuk, melatih, membina, memfasilitasi, menumbuh-kembangkan partisipasi serta memantau dan mengevaluasi program Desa Siaga, seperti penuturan informan berikut:

"...Peran petugas puskesmas adalah membina, memberi bantuan peralatan, memberikan penyuluhan, dan melatih serta memfasilitasi masyarakat untuk pelaksanaan program Desa Siaga..." (Srt, Bandung, 23 Agustus 2013).

“...Peran petugas puskesmas dan sektor terkait di tingkat kecamatan adalah mengusahakan kemudahan masyarakat dalam melaksanakan program Desa Siaga. Petugas puskesmas memberikan pembinaan kepada masyarakat dalam melakukan identifikasi masalah kesehatan, cara memecahkan masalah kesehatan, cara memanfaatkan potensi sumber daya lokal, dan menumbuh-kembangkan partisipasi." (Ans, Bulus, 22 Agustus 2013)

“...Petugas kesehatan berperan dalam meningkatkan kemampuan mengidentifikasi dan memecahkan masalah kesehatan lokal..." (Ss, Bandung, 24 Agustus 2013)

\footnotetext{
Peran Fasilitator dalam Pemberdayaan Masyarakat Bidang Kesehatan

Sebagian besar informan menjelaskan bahwa peran
}

fasiltator program Desa Siaga adalah melakukan sosialisasi, pendampingan, motivator, pengarah, mediator antara masyarakat dengan pemerintah, memengaruhi pengambilan keputusan, dan menumbuh-kembangkan partisipasi. Hal tersebut seperti penuturan informan berikut:

“...Fasilitator berperan sebagai penyuluh dan penghubung antara masyarakat dan pemerintah, mengarahkan masyarakat dalam melaksanakan kegiatan program Desa Siaga, menampung aspirasi masyarakat untuk disampaikan kepada pemerintah, dan menumbuhkembangkan partisipasi..." (Srt, Bulus, 22 Agustus 2013).

“...Fasilitator berperan sebagai pendamping, yaitu mendampingi proses pengenalan masalah kesehatan, membantu memperoleh sumber-sumber daya yang diperlukan, membantu memilih pemecahan masalah kesehatan yang sesuai dengan kondisi masyarakat." (Spd, Bandung, 23 Agustus 2013).

"Peran fasilitator adalah sebagai motivator, yaitu memberikan dorongan kepada warga masyarakat untuk mampu mengidentifikasi dan memecahkan masalah kesehatan”. (Wt, Bulus, 22 Agustus 2013)

\section{Pembahasan \\ Peran Kepemimpinan dalam Pemberdayaan Masyarakat Bidang Kesehatan}

Penelitian Adrian, 13 menyimpulkan bahwa kepemimpinan masyarakat berperan untuk mengikutsertakan masyarakat lokal dalam program pembangunan. Sinergi yang jelas di antara mereka untuk berperan saling melengkapi. Bukti dampak dari kepemimpinan masyarakat menunjukkan adanya keikutsertaan masyarakat ke dalam ruang tata kelola masyarakat, dan menekankan kebutuhan untuk menggerakan kepemimpinan lokal yang kuat.

Penelitian Ferguson et al, ${ }^{14}$ memberikan kerangka teoritis untuk memahami cara masyarakat memandang peluang kepemimpinan dalam lembaga masyarakat serta proses lembaga mendorong peningkatan keikutsertaan. Empat tema utama yang muncul, yaitu suara masyarakat dan kepemilikan, keamanan emosional, kekuasaan, dan dukungan timbal balik. Untuk keberhasilan pemberdayaan masyarakat, perlu ditunjang dengan pemberdayaan kepemimpinan. Pitts, ${ }^{15}$ memformulasikan secara komprehensif definisi dari pemberdayaan kepemimpinan yang meliputi tujuh dimensi, yaitu kekuasaan, pengambilan keputusan, informasi, otonomi, inisiatif dan kreativitas, pengetahuan dan keterampilan, dan pertanggungjawaban. Penelitian Ashwell et al, ${ }^{6}$ menegaskan bahwa kemandirian berkelanjutan di bidang kesehatan dapat dicapai melalui kepemimpinan masyarakat dan mempertahankan aktivitas, menguatkan intervensi pogram dan meningkatkan interaksi antara masyarakat 
dan sistem kesehatan serta meningkatkan penggunaan pelayanan kesehatan oleh masyarakat.

\section{Peran Modal Sosial dalam Pemberdayaan Masyarakat Bidang Kesehatan}

Modal sosial menurut Lynch et al,16 merupakan kemampuan sosial yang lebih luas menyangkut inklusivitas, hak asasi manusia, keadilan sosial, partisipasi ekonomi, dan politik secara penuh dari warga masyarakat sehingga investasi modal sosial merupakan strategi yang berguna untuk kesehatan masyarakat. Selanjutnya, penelitian Nina, ${ }^{17}$ menyimpulkan bahwa pemberdayaan disajikan dan dibandingkan dengan modal sosial dan kapasitas masyarakat sebagai strategi untuk memperkuat faktor perlindungan sosial.

Penelitian Lopez, ${ }^{18}$ menemukan hubungan antara peningkatan inovasi dan tingkat modal sosial yang berbeda. Penelitian ini menjelaskan hubungan antara pemberdayaan dan tujuan inovasi dalam peningkatan kondisi kehidupan berdasarkan perbedaan tingkatan modal sosial. Promosi kesehatan dalam modal sosial dan pemberdayaan dapat menyumbangkan pengaruh pada pembangunan melalui aksi perorangan ataupun masyarakat yang didukung oleh kebijakan dan program. Terdapat hubungan antara pemberdayaan modal sosial (struktur dan nilai) dan inovasi dalam organisasi masyarakat pada daerah pedesaan di Peru.

\section{Peran Akses Informasi dalam Pemberdayaan Masyarakat Bidang Kesehatan}

Hasil studi kasus menunjukkan bahwa akses informasi kesehatan berperan dalam pemberdayaan masyarakat. Hal tersebut sejalan dengan pendapat Rothman, ${ }^{19}$ bahwa peran akses informasi kesehatan meliputi pengetahuan tentang kesehatan dan perawatan kesehatan, kemampuan untuk menemukan, memahami, menginterpretasikan dan mengkomunikasikan informasi kesehatan, kemampuan untuk meminta perawatan kesehatan yang tepat dan membuat keputusan kesehatan secara kritis. Pelbagai jenis informasi berperan dalam peningkatan pengetahuan, sikap, dan keterampilan masyarakat untuk hidup bersih dan sehat. Masyarakat memahami cara-cara melakukan identifikasi dan pemecahan masalah kesehatan. Akses informasi akan mendorong masyarakat untuk berpartisipasi dalam pembangunan kesehatan, baik pada tingkat individu maupun pada kelompok masyarakat.

\section{Peran Petugas Kesehatan dalam Pemberdayaan Masyarakat Bidang Kesehatan}

Terungkap melalui studi kasus bahwa petugas kesehatan berperan dalam pemberdayaan masyarakat bidang kesehatan. Menurut Sulaeman, ${ }^{7}$ petugas kesehatan berperan dalam melakukan pendekatan kepada pe- mangku kepentingan dan masyarakat agar mereka menjadi sadar terhadap permasalahan yang dihadapi di desanya, bangkit niat dan tekad untuk mencari solusi serta memantau, membina pelaksanaan survei mawas diri dan musyawarah masyarakat desa sebagai media untuk mengidentifikasi masalah kesehatan dan merumuskan pemecahan masalah kesehatan, juga melakukan pendampingan yang berperan sebagai fasilitator.

Petugas kesehatan perlu memahami kebutuhan masyarakat, budaya masyarakat, dan karakteristik kepribadian masyarakat. Petugas kesehatan berupaya mengembangkan pembelajaran bagi masyarakat untuk membangun kemandirian dalam pemecahan masalah kesehatan. Peran petugas kesehatan adalah sebagai fasilitator berperan untuk memberikan kemudahan bagi masyarakat dalam memperoleh pelayanan kesehatan, memfasilitasi terpenuhinya kebutuhan sarana dan peralatan untuk mendukung kelancaran kegiatan Desa Siaga, sebagai konsultan dengan memberikan nasihat dan petunjuk kepada masyarakat agar pelaksanaan kegiatan program Desa Siaga dapat berjalan sesuai dengan tujuan. ${ }^{20}$

Kementerian Kesehatan (Kemenkes), ${ }^{21}$ menegaskan bahwa keberhasilan program kesehatan ditentukan oleh peran petugas kesehatan di antaranya pertama adalah kinerja profesional, yaitu upaya sistematis yang dilakukan dalam aktivitas kerja yang diwujudkan dalam penampilan kinerja. Kedua adalah persepsi terhadap perilaku kepemimpinan, yaitu perilaku positif dari pemimpin yang merupaka panutan yang memengaruhi peran pegawai. Ketiga adalah kompetensi, yaitu kemampuan pegawai untuk mendemonstrasikan pengetahuan dan keterampilannya untuk menghasilkan jasa layanan kesehatan sesuai dengan standar yang ditetapkan, dan kemampuan untuk mengalihkan pengetahuan dan keterampilan. Keempat adalah kompensasi, yaitu faktor eksternal yang secara langsung memengaruhi peran pegawai dalam proses penggerakan dan pemberdayaan, seperti gaji, penghargaan, dan fasilitas. Kelima adalah sikap pegawai terhadap pekerjaan, yaitu sikap positif terhadap pekerjaan yang akan mendorong kemampuan menerjemahkan lingkungan untuk diwujudkan dalam kinerja pegawai. Keenam adalah motivasi kerja, yaitu daya dorong sebagai hasil proses interaksi dengan lingkungan. Ketujuh adalah kecerdasan emosi, yaitu kesadaran, pengendalian diri dan kemampuan atau kekuatan pribadi, sosial, politik, ekonomi yang diwujudkan dalam bentuk kinerja sebagai hasil interaksi dengan lingkungan.

\section{Peran Fasilitator dalam Pemberdayaan Masyarakat Bidang Kesehatan}

Fasilitator menciptakan suasana dialogis dengan masyarakat dan mampu menumbuhkembangkan, meng- 
gerakkan, serta memelihara partisipasi masyarakat dalam program pemberdayaan masyarakat bidang kesehatan, mulai dari perencanaan sampai dengan evaluasi hasil kegiatan.

Peran fasilitator menurut Mardikanto, 22 adalah memengaruhi proses pengambilan keputusan yang dilakukan oleh masyarakat untuk mengadopsi inovasi, meningkatkan kapasitas individu, entitas, dan jejaring yang terhimpun dalam satu kata "edfikasi" sebagai akronim dari edukasi, diseminasi informasi/inovasi, fasilitasi, konsultasi, supervisi, pemantauan, dan evaluasi. Sementara itu, peran fasilitator menurut Yoo et al, ${ }^{3}$ adalah untuk memberikan bantuan dan bimbingan serta tetap menjaga hubungan yang erat dengan masyarakat, namun tidak mengarahkan atau memengaruhi keputusan masyarakat.

\section{Kesimpulan}

Peran kepemimpinan dalam pemberdayaan masyarakat bidang kesehatan pada program Desa Siaga adalah menyebarluaskan informasi, memberikan contoh, penyadaran, memotivasi, membimbing, menggerakkan sasaran dan masyarakat, memfasilitasi dan mengalokasikan sumber daya. Sementara itu, peran modal sosial adalah saling percaya, kekerabatan, pertetanggaan dan pertemanan, norma sosial, kerjasama, tolong-menolong, dan adanya jaringan masyarakat. Peran akses informasi kesehatan adalah meningkatkan pengetahuan dan keterampilan kesehatan, mengambil keputusan kesehatan, dan meminta pelayanan kesehatan. Peran petugas kesehatan adalah melakukan sosialisasi, memberikan petunjuk, melatih, membina, memfasilitasi, menumbuhkembangkan partisipasi, serta memantau dan mengevaluasi program pemberdayaan masyarakat. Kemudian, peran fasilitator kesehatan adalah melakukan sosialisasi, pendampingan, motivator, mediator antara masyarakat dan pemerintah, memengaruhi pengambilan keputusan, dan menumbuhkembangkan partisipasi.

\section{Saran}

Berdasarkan temuan penelitian, disarankan untuk memperkuat peran kepemimpinan dalam pemberdayaan masyarakat bidang kesehatan, yaitu peran penyebarluasan informasi, pemberian contoh, penyadaran, pemberian motivasi, pembimbingan, penggerakkan sasaran dan masyarakat, fasilitasi dan pengalokasian sumber daya. Selain itu, memperkuat peran modal sosial, yaitu saling percaya, kekerabatan, pertetanggaan dan pertemanan norma sosial, kerja sama, tolong-menolong, serta adanya jaringan masyarakat. Memperkuat peran akses informasi kesehatan, yaitu peningkatan pengetahuan dan keterampilan kesehatan, pengambilan keputusan kesehatan, dan meminta pelayanan kesehatan. Memperkuat peran petugas kesehatan, yaitu melakukan sosialisasi, mem- berikan petunjuk, melatih, membina, memfasilitasi, menumbuh-kembangkan partisipasi serta memantau dan mengevaluasi program pemberdayaan masyarakat. Selain itu, disarankan untuk memperkuat peran fasilitator dengan melakukan sosialisasi, pendampingan, motivator, mediator antara masyarakat dan pemerintah, memengaruhi pengambilan keputusan, dan menumbuhkembangkan partisipasi.

\section{Daftar Pustaka}

1. Kementerian Perencanaan Pembangunan Nasional Badan Perencanaan Pembangunan Nasional (BAPPENAS). Laporan pencapaian tujuan pembangunan milenium Indonesia 2010. Jakarta: Kementerian Perencanaan Pembangunan Nasional Badan Perencanaan Pembangunan Nasional; 2010.

2. Sulaeman ES, Karsid R, Murti B, Kartono DT, Waryana, Hartanto R. Model pemberdayaan masyarakat bidang kesehatan, studi program desa siaga. Kesmas: Jurnal Kesehatan Masyarakat Nasional. 2012; 7 (4): 186-92.

3. Yoo S, Weed NE, Lempa ML, Mbondo M, Shada RE, Goodman RM. Collaborative community empowerment: an illustration of a six-step process. Health Promotion Practice. 2004; 5 (3): 256-65.

4. Rehn NS, Ovretveit J, Laamanen R, Suominen S, Sundell J, Brommels M. Determinants of health promotion action: comparative analysis of local voluntary associations in four municipalities in Finland. Health Promotion International. 2006; 21 (4): 274-83.

5. Sulaeman ES, Karsid R, Murti B, Kartono DT, Waryana, Hartanto R. Leadership, social capital, access to information and community empowerment to address health issues. International Journal of Scientific Research and Education (IJSRE). 2013; 1 (5): 90-107.I

6. Ashwell HES, Barclay L. A retrospective analysis of a community-based health program in Papua New Guinea. Health Promotion International. 2009; 24 (2): 140-8

7. Sulaeman ES, Karsid R, Murti B, Kartono DT, Waryana, Hartanto R. Model Pemberdayaan masyarakat dalam kemampuan mengidentifikasi masalah kesehatan: studi pada program desa siaga. Jurnal Kedokteran YARSI. 2012; 20 (3): $118-27$.

8. Macinko J, Startfiiel B. The utility of social capital in research on health determinants. The Johns Hopkins Medical Institutions. 2001; 79 (3): 387-427.

9. Keleher H, Mac DC. Understanding health a determinants approach. 2nd Edition. Australia and New Zealand: Oxford University Press; 2009.

10. Fineberg H. Health literacy, Institute of Medicine. The National Academics Press; 2004

11. Kementerian Kesehatan RI. Pedoman pengembangan desa siaga. Lampiran Keputusan Menteri Kesehatan RI Nomor 564/Menkes/VIII/2006. Jakarta: Kementerian Kesehatan RI; 2006.

12. Dinas Kesehatan Kabupaten Tulungagung. Profil kesehatan Kabupaten Tulungagung. Tulungagung: Dinas Kesehatan Kabupaten Tulungagung; 2012.

13. Adrian M. The community leadership and place-shaping roles of english local government synergy or tension? Public Policy and Administration. 2010; 25 (5): 175-87.

14. Ferguson KM, Kim MA, McCoy S. Enhancing empowerment and lead- 
ership among homeless youth in agency and community settings: a grounded theory approach. Child Adolescence Social Worker Journal. 2011; 28 (4):1-22.

15. Pitts DW. Leadership, empowerment, and public organizations. Review of Public Personnel Administration. 2005; 25 (3): 5-17.

16. Lynch J, Due P, Muntaner C, Smith GD. Social capital - is it a good investment strategy for public health? Journal of Epidemiol Community Health. 2000; 54 (5): 404-8.

17. Nina W. Empowerment to reduce health disparities. Scandinavian Journal of Public Health. 2002; 30: 72-7.

18. Lopez LH. Assering rural community empowerment what it takes to think innovatively a doctoral research proposal. Journal of Centrum Cathedra. 2009; 12 (4): 145-63.

19. Rothman J, Tropman JE. Models of community organization and macro practice: their mixing and phasing in strategies of community organization [online]. 4th ed. FM. Cox et al. Eds: Itasca; Peacocok Publ: 1987 [accessed on Thursday March 2014]. Available from: http://is.muni.cz/el/1423/podzim2010/SPP815/um/15.rothman.pdf.

20. Kementerian Kesehatan Republik Indonesia kerjasama dengan Kementerian Dalam Negeri RI. Keputusan menteri kesehatan Republik Indonesia No.1529/Menkes/SK/X/2010. Pedoman umum pengembangan desa dan kelurahan siaga aktif. Jakarta: Kementerian Kesehatan Republik Indonesia; 2010.

21. Departemen Kesehatan Republik Indonesia. Jalan setapak menuju Indonesia sehat melalui pemberdayaan sumberdaya manusia kesehatan. Jakarta: Departemen Kesehatan Republik Indonesia; 2004

22. Mardikanto T. Konsep-konsep pemberdayaan masyarakat acuan bagi aparat birokrasi, akademisi, praktisi, dan peminat/pemerhati pemberdayaan masyarakat. Cetakan ke-1. Surakarta: Kerjasama Fakultas Pertanian UNS dengan UPT Penerbitan dan Percetakan UNS (UNS Press); 2010. 